\title{
有機カチオン膜輸送体による神経幹細胞の機能制御と精神神経疾患治療への応用
}

\author{
中道範 隆, ${ }^{*, \uparrow}$ 増尾友 佑, 加藤 将夫
}

\section{Possible Treatment of Neuropsychiatric Disorders by Promotion of Neuronal Differentiation through Organic Cation Transporters}

\author{
Noritaka Nakamichi, ${ }^{*, \uparrow}$ Yusuke Masuo, and Yukio Kato \\ Faculty of Pharmacy, Kanazawa University; Kakuma-machi, Kanazawa, Ishikawa 920-1192, Japan.
}

(Received August 8, 2018)

\begin{abstract}
Neurons differentiated from neural stem cells mature to form a neuronal network. Neuronal maturation enables neurotransmission that regulates brain function. Therefore, abnormal neuronal differentiation causes dysfunction in neurotransmission, and is involved in the onset of various neuropsychiatric disorders. Most of the drugs currently available for the treatment of neuropsychiatric disorders act on membrane receptors and reuptake transporters of neurotransmitters, and control neurotransmission. These membrane proteins have a high affinity for a specific neurotransmitter, and are highly expressed in synapses. By contrast, xenobiotic transporters have a relatively lower affinity for neurotransmitters, but widely recognize various organic compounds, and are also expressed in brain neural cells. It has remained largely unknown why such xenobiotic transporters are expressed in neural cells that play a key role in neurotransmission. We have therefore attempted to clarify the physiological roles of organic cation transporters (OCTs) in neural stem cells in order to obtain new insight into the treatment of neuropsychiatric disorders. The carnitine/organic cation transporter OCTN1/SLC22A4 is expressed at much higher levels in neural stem cells compared with other OCTs, and promotes their differentiation into neurons through the uptake of the food-derived hydrophilic antioxidant ergothioneine after oral administration. In this review, we introduce current topics on the physiological/pathophysiological roles of OCTs in neural stem cells, and discuss their possible application to the treatment of neuropsychiatric disorders.
\end{abstract}

Key words — neural stem cell; organic cation transporter; neuropsychiatric disorder; neuronal differentiation; carnitine/organic cation transporter 1; ergothioneine

\section{はじめに}

神経幹細胞は, 神経細胞, アストロサイト, オリ ゴデンドロサイトへの多分化能を有したまま自己複 製できる未分化細胞であり, 発達脳において豊富に 存在するが成体脳では減少する。一方，ヒトを含む 哺乳動物の成体脳においても海馬歯状回や側脳室下 帯において, 神経新生が確認されている. 1,2) 神経幹 細胞から分化した神経細胞が成熟して神経回路網を 形成し，神経細胞間で情報伝達が行われることによ り正常な脳機能が発揮される。哺乳動物中枢神経細 胞はひどく損傷を受けると再生できない3,4)ことか

金沢大学医薬保健研究域薬学系（干920-1192 石川県金 沢市角間町)

現所属: †高崎健康福祉大学薬学部（干370-0033 群馬 県高崎市中大類町 60)

*e-mail: nakamichi@takasaki-u.ac.jp

本総説は, 日本薬学会第 138 年会シンポジウム S42 で 発表した内容を中心に記述したものである.
ら，神経幹細胞による神経細胞の補填が脳機能の恒 常性維持に重要である。したがって, 神経幹細胞の 神経分化能の異常は, 神経情報伝達障害を引き起こ す一因となり, 種々の精神神経疾患の発症や増悪に 関与する. 実際に神経新生の抑制はうつ病や認知症 の発症と関連し, ${ }^{5-7)}$ 抑制された神経新生を緩和す ることで抑うつ症状が改善される。 ${ }^{8,9)}$ また，うつ病 治療薬には神経新生促進作用を有するものが多 い. 10-12) したがつて, 神経幹細胞の神経分化促進は うつ病を始めとする精神神経疾患の有力な治療戦略 である。

臨床使用されている精神神経疾患治療薬の多く は，情報伝達物質の受容体や再取り込み膜輸送体に 作用して神経情報伝達を調整する。これら臨床使用 薬の標的となる膜タンパク質は, 特定の神経伝達物 質に対し高い選択性と親和性を示し，シナプスに高 発現する。一方，特定の化合物に高い親和性を示さ 
ず幅広い基質認識性を有する異物取り込み膜輸送体 が，神経細胞や神経幹細胞に機能的に発現すること が近年報告されている. ${ }^{13,14)}$ 高度な脳機能の維持に 働く神経細胞や神経幹細胞に生体異物を取り込む膜 輸送体が存在すること自体が謎であり，神経系細胞 における役割はほとんど明らかとなっていない。そ こで異物取り込み膜輸送体の神経幹細胞における （病態）生理学的意義を解明することにより，精神 神経疾患治療に新たな知見を得ようと試みた。

\section{神経幹細胞に発現する有機力チオン膜輸送体}

神経幹細胞の細胞膜には種々の膜受容体や膜輸送 体が発現している。神経幹細胞は情報伝達を行う神 経細胞とは異なりシナプスを形成しないことから， 神経伝達物質による膜受容体の活性化よりも，膜輸 送体による細胞内の生理活性物質濃度の制御が細胞 の機能調節に重要と考えられる．膜輸送体はその性 質から次の 3 つに分類することができる．ATP 依 存的に細胞内の不要物を能動的に細胞外へと汲夕出 す排出膜輸送体．情報伝達物質やアミノ酸など細胞 活動に必要な物質を細胞内へと取り込む生理的膜輸 送体。そして，生体異物を細胞内へと輸送する異物 取り込み膜輸送体である。異物取り込み膜輸送体 は，肝臓や腎臓に発現し，薬など生体異物の代謝や 排泄に関与する，前者 2 つ膜輸送体は，細胞増殖 を繰り返す代謝能の高い神経幹細胞に発現すること は理にかなっており，実際に神経幹細胞に機能的に 発現している. ${ }^{15-18)}$ 一方, 異物取り込み膜輸送体も また神経幹細胞に発現するが，その生理的役割は明 らかとなっていない。神経細胞では異物取り込み膜 輸送体の中でも有機カチオン膜輸送体が疾患時にモ ノアミン神経伝達物質の低親和性膜輸送体として働 く可能性が示されている19,20)が，シナプスを形成し ない神経幹細胞での役割は不明である。そこで異物 取り込み膜輸送体の中でも有機カチオン膜輸送体に 着目し，まずどのような有機カチオン膜輸送体が神 経幹細胞に発現するのかを明らかにした.

マウス由来培養神経幹細胞における有機力チオン 膜輸送体の発現について調べたところ，特異な発現 プロファイルを示した. Carnitine/organic cation transporter 1（OCTN1）の発現が顕著に高く, 次に OCTN2 及び OCTN3 がわずかに発現しており，そ の他の有機力チオン膜輸送体 organic cation transporter (OCT) 1-3, multidrug and toxic compound extrusion (MATE), plasma membrane monoamine transporter（PMAT）はいずれも定量限界以下 （<60 copies/ $\mu \mathrm{g}$ total RNA）であつた. ${ }^{14)}$ 野生型 （WT）マウス由来の神経幹細胞は OCTN1 に特異 性の高い基質 ergothioneine（ERGO）を時間依存的 に取り込んだが，octn1 遺伝子欠損 $\left(\right.$ octn1 $\left.1^{-/-}\right)$ マウス由来の神経幹細胞は ERGO をほとんど細胞 内に取り込まなかった。したがって，神経幹細胞に は OCTN1 が主要な有機カチオン膜輸送体として機 能的に発現しており, 細胞の機能調節になんらかの 役割を果たしていると推察される。そこでわれわれ は神経幹細胞に発現する有機カチオン膜輸送体とし て OCTN1/SLC22A4 に着目することにした。

膜輸送体 OCTN1 は，SLC22A ファミリーに属す る膜輸送体であり, OCT と $30 \%$ 程度の相同性を示 す。同膜輸送体は，有機力チオン性化合物を $\mathrm{pH}$ 依 存的に, 食物由来の抗酸化物質 $\mathrm{ERGO}$ を $\mathrm{Na}^{+}$依 存的に輸送する。また，OCTN1 は神経幹細胞のほ

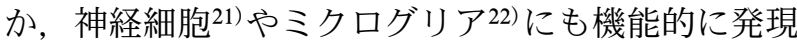
しており，脳以外にも腎臓，肝臓，消化管等全身に 幅広く発現している. ${ }^{23-25)} \mathrm{WT}$ マウスでは脳を含む ほぼすべての臓器において食物由来と思われる ERGO が検出されるが，octn1 1 - - マウスでは検出 限界以下となる. ${ }^{26)}$ 以上のように，生体内の ERGO 濃度は膜輸送体 OCTN1 により制御されている。そ こで次に，膜輸送体 OCTN1 が良好な in vivo 基質 ERGO を細胞内へ取り込むことにより，神経幹細 胞の分化能にどのような影響を及ぼすのかについて 検討を加えた.

\section{有機力チオン膜輸送体 OCTN1による神経幹細胞 の神経分化促進}

培養神経幹細胞に抗酸化物質 ERGO を曝露する と, 神経分化促進因子 Math1 の誘導を伴い, 神経 細胞への分化が促進され，アストロサイトへの分化 は抑制された（Fig. 1). ${ }^{14)}$ 一方，抗酸化物質 edaravone, ascorbic acid への曝露は, 神経幹細胞の分化 能にほとんど影響を及ぼさなかった。これら 3 つの 抗酸化物質はいずれも神経幹細胞内の活性酸素種を 減少させた（Fig. 1)。また，WT 由来の神経幹細胞 では ERGO 曝露による神経分化促進がみられたが, octn1-ノ- マウス由来の神経幹細胞では ERGO 曝 露による神経分化促進は起こらなかった。したがっ て, 膜輸送体 OCTN1 を介した ERGO の神経幹細 


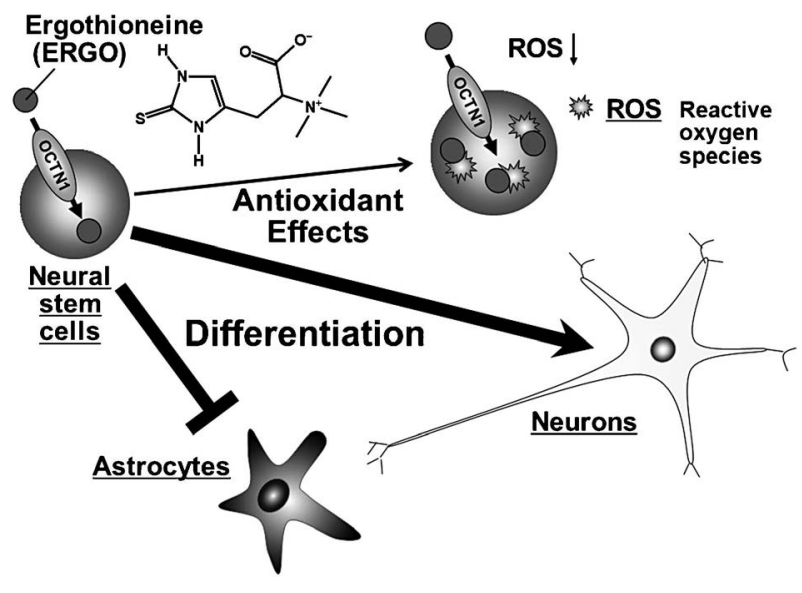

Fig. 1. Physiological Roles of OCTN1-mediated Uptake of ERGO in Neural Stem Cells

ERGO is transported into the intracellular space by OCTN1 and deletes reactive oxygen species. ERGO promotes cellular differentiation into neurons and suppresses them into astrocytes through unidentified mechanisms independent of its antioxidant effects.

胞内への取り込みは，抗酸化作用以外のメカニズム を介して神経分化を促進する（Fig. 1)。そこで次 に，膜輸送体 OCTN1 を介した ERGO の取り込み がごのようなメカニズムで神経分化を促進するのか について検討を加えた.

Mammalian target of rapamycin (mTOR) complex 1 （mTORC1）は細胞内アミノ酸センサーとして働 き，細胞の増殖や分化を制御する. ${ }^{27,28)} \mathrm{ERGO}$ はア ミノ酸である（Fig. 1）ことから， mTORC1 の活 性化を介して神経分化を促進する可能性が考えられ る。 mTORC1の阻害剂である rapamycinは, ERGO による神経分化の促進を抑制した。また, 培養神経幹細胞に ERGO を曝露すると, mTORC1 及びその下流シグナルである p70 ribosomal protein S6 kinase 1 のリン酸化タンパクの発現が増加した.

したがって, ERGO は mTORC1 シグナルの活性化 を介して神経分化を促進することが示唆された。

ERGO は神経新生の促進を介して抗うつ様作用を 示す29)ことから， ERGO は mTORC1 シグナルの活 性化を介して抗うつ効果を発揮する可能性がある. 抗うつ薬である選択的セロトニン再取り込み阻害薬 (selective serotonin reuptake inhibitor; SSRI) もまた mTORC1 シグナルを活性化し，その活性化を介し て抗うつ効果を発揮する. ${ }^{30,31)}$ SSRI が mTORC1 シ グナルを活性化するのに数日を要する30)のに対して, ERGO は数時間以内に $\mathrm{mTORC} 1$ を活性化させた. 臨床使用されている抗うつ薬が効果を発揮するまで
に数週間を要することが問題となっており，その一 因として SSRI は mTORC1 の活性化に時間を要す ることが挙げられる. ${ }^{31-33)} \mathrm{mTORC1}$ シグナルを素 早く活性化する化合物が即効性の抗うつ効果を有す る可能性があり，近年麻酔薬の ketamine が mTORC1 を短時間で活性化させ，即効性の抗うつ 効果を示すことが報告されている. ${ }^{32-34)}$ 神経幹細胞 における mTORC1 シグナルの素早い活性化が即効 性の抗うつ効果と関連するのかは明らかとなってい ないが， ketamine と同じく ERGO も即効性の抗う つ効果を示すのかは, 今後の重要な検討課題である.

神経栄養因子 brain-derived neurotrophic factor (BDNF) は，ERGO と同様に神経分化促進因子 Math1 の誘導を伴い神経分化を促進する35) ことか ら，ERGO が神経栄養因子を誘導する可能性につ いても検討を加えた。培養神経幹細胞に ERGO を 曝露すると, 曝露 12 時間後から神経栄養因子 neurotrophin 5 (NT5) が有意に誘導された。しかしな がら, ERGO は他の神経栄養因子 nerve growth factor, BDNF, neurotrophin 3 は誘導しなかった. ERGO による神経分化の促進は，NT5 に対する受 容体の 1 つである tropomyosin receptor kinase B （TrkB）の阻害剤により抑制された。また，培養神 経幹細胞に ERGO を曝露すると, TrkBのリン酸化 タンパクの発現が増加した。したがって, ERGO はNT5 の誘導及びそれに続く TrkB の活性化を介 して神経分化を促進する可能性が示された，BDNF と同様に神経栄養因子 NT5 もまた，うつ病の発症 に関与することが示されている. ${ }^{36)}$ SSRI は BDNF を誘導するのに対して ERGO はNT5 を誘導するこ とから，SSRI と ERGO は異なるメカニズムで抗う つ効果を発揮する可能性がある。遺伝子変異により BDNF の分泌が低下するうつ病患者では SSRI に対 して抵抗性を示すことが問題となっており, ${ }^{37,38)}$ ERGO は SSRI 治療抵抗性の患者に対して有効かも しれない.

膜輸送体 OCTN1 を標的とした精神神経疾患治療 の可能性

OCTN1 の良好な in vivo 基質 ERGO は食品由来 の抗酸化物質であり, 哺乳動物の脳において組織 $100 \mathrm{~g}$ あたり $0.2-1 \mathrm{mg}$ 程度検出される. ${ }^{26,39)}$ 脳室内 投与された ERGO は海馬や大脳皮質ほか，いずれ の脳領域にも広く分布する. ${ }^{21)}$ また，各脳領域にお 
ける ERGO 濃度は OCTN1 の発現レベルと正の相 関を有する. ${ }^{21)}$ 他の藏器と同様に, 脳の各領域にお いても ERGO の分布は膜輸送体 OCTN1 によって 制御されると推察される。 ERGO を混餌によって マウスに摂取させると，血液，血漿，脳，肝臓，腎 臓のいずれにおいても投与量依存的に組織中の ERGO 濃度は増加した. ${ }^{29)}$ また，海馬歯状回におけ

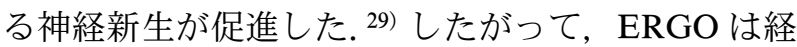
口摂取後に消化管吸収されて，血液脳関門を通過し て脳へと分布し，海馬歯状回における神経新生を促 進する可能性が示された.

ERGO の経口摂取は抗うつ薬のスクリーニング 系として汎用される強制水泳試験及び尾懸垂試験に おいてマウスの無動時間を有意に短縮したことから,

ERGO の経口摂取により抗うつ効果が発揮される 可能性が示された. ${ }^{29)}$ 尾懸垂試験においては $12 \mathrm{mg} /$ $100 \mathrm{~g}$ diet の ERGO 投与量から効果がみられ，これ は体重 $70 \mathrm{~kg}$ のヒトに換算するとおおよそ $100 \mathrm{mg} / \mathrm{d}$ の摂取量となり，容易に摂取可能な量である. ${ }^{29)} こ$ のように水溶性低分子化合物の低用量摂取で抗うつ 効果が発揮されることは大変興味深い。これまでに も resveratrol や curcumin が抗うつ効果を発揮する 可能性が示されている40,41)が，それらはいずれも疎 水性化合物であり，経口摂取後の体内動態に不明な 点が多い。また，脳内移行性がよくないため効果を 発揮するのに高用量摂取する必要があり, resveratrol や curcumin の高用量長期摂取は肝障害を引き 起こす. ${ }^{42,43)}$ 予期せぬ副作用を避けるためにも， ERGO のように 1 つの膜輸送体により体内動態が 制御される水溶性低分子化合物に着目して創薬を進 めることは有力な戦略である，次に，うつ病以外の 精神神経疾患治療の可能性についても考察した。

ERGO の経口摂取は記憶学習障害マウスにおい て記憶学習能力の改善効果を示す. ${ }^{44)}$ また，ヒトに おいて軽度認知機能障害患者の血液45)やパーキンソ ン病患者の血清46) 中の ERGO 濃度が低下する。こ れらは ERGO が抗酸化作用や神経分化促進作用に よって脳の恒常性維持に重要な役割を果たしている ことを示唆する．脳内 $\mathrm{ERGO}$ 濃度の低下は精神神 経疾患をより発症し易くするのかもしれない。実際 にヒトにおいて, 膜輸送体 OCTN1 の遺伝子変異は 炎症性疾患であるクローン病や関節リウマチの発症 に関与することが示されている. ${ }^{26,47,48)}$ 膜輸送体

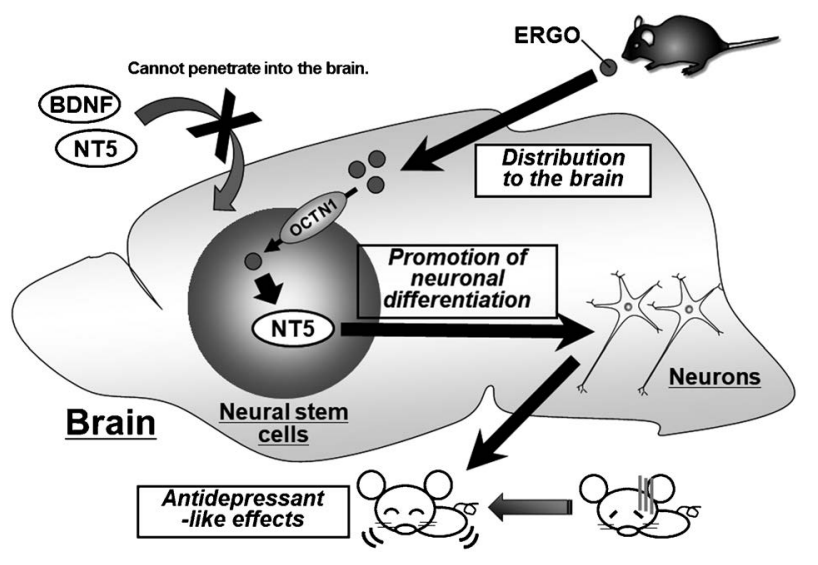

Fig. 2. Physiological Roles of OCTN1-mediated Uptake of ERGO in the Brain

ERGO is highly distributed in the brain after oral ingestion, promotes cellular differentiation into neurons through the induction of NT5 in neural stem cells, and exerts antidepressant-like effects. Although intracerebrally administered neurotrophic factors also promote neuronal differentiation of neural stem cells, peripherally administered neurotrophic factors cannot penetrate into the brain across the blood-brain barrier.

OCTN1 の機能と精神神経疾患に対する脆弱性が関 連するのかは，今後の重要な検討課題である.

おわりに

神経幹細胞に発現する有機カチオン膜輸送体の生 理的役割を解明することにより，経口摂取された水 溶性アミノ酸 ERGO が血液脳関門を通過して脳内 へと移行し，膜輸送体 OCTN1によって神経幹細胞 内に取り込まれた後, 神経栄養因子 NT5 を誘導し て神経分化を促進し，抗うつ作用を発揮する可能性 が示された (Fig. 2)。精神神経疾患の根本的治療 が困難な要因として，損傷を受けた哺乳動物中枢神 経細胞は再生できないことが挙げられる. ${ }^{3,4)}$ 一方, 近年ヒト成体脳でも神経新生が起こることが明らか となり, 1,2) 内在性神経幹細胞の活性化による精神神 経疾患治療が着目されている。神経新生促進作用を 有する神経栄養因子 BDNF を脳室内投与すると抗 うつ効果が示される49)が，末梢投与では神経栄養因 子は脳内に移行しない50) た, 脳移行性が臨床応用 の障壁となる（Fig. 2)。したがって，有機力チオ ン膜輸送体基質の経口投与により，脳内で神経栄養 因子を誘導して神経分化を促進する本アプローチ は，精神神経疾患の有用な治療戦略となる，以上の ように，神経幹細胞の神経分化を制御する有機力チ オン膜輸送体 OCTN1 は，精神神経疾患の新規治療 標的分子として期待される. 
謝辞 本研究の遂行にあたり，多大なるご協力 を頂きました金沢大学医薬保健研究域薬学系分子薬 物治療学研究室のメンバーに深く感謝致します.

利益相反＼cjkstart開示すべき利益相反はない.

\section{REFERENCES}

1) Knoth R., Singec I., Ditter M., Pantazis G., Capetian P., Meyer R. P., Horvat V., Volk B., Kempermann G., PLoS One, 5, e8809 (2010) .

2) Ming G. L., Song H., Neuron, 70, 687-702 (2011).

3) Horner P. J., Gage F. H., Nature, 407, 963970 (2000).

4) Hilliard M. A., J. Neurochem., 108, 23-32 (2009).

5) Eisch A. J., Petrik D., Science, 338, 72-75 (2012).

6) LaDage L. D., Integr. Comp. Biol., 55, 372383 (2015).

7) Le Grand J. N., Gonzalez-Cano L., Pavlou M. A., Schwamborn J. C., Cell Mol. Life Sci., 72, 773-797 (2015).

8) Sahay A., Hen R., Nat. Neurosci., 10, 11101115 (2007).

9) Snyder J. S., Soumier A., Brewer M., Pickel J., Cameron H. A., Nature, 476, 458-461 (2011).

10) Warner-Schmidt J. L., Duman R. S., Hippocampus, 16, 239-249 (2006).

11) Li Y., Luikart B. W., Birnbaum S., Chen J., Kwon C. H., Kernie S. G., Bassel-Duby R., Parada L. F., Neuron, 59, 399-412 (2008).

12) Perera T. D., Park S., Nemirovskaya Y., Neuroscientist, 14, 326-338 (2008).

13) Sanchez-Covarrubias L., Slosky L. M., Thompson B. J., Davis T. P., Ronaldson P. T., Curr. Pharm. Des., 20, 1422-1449 (2014).

14) Ishimoto T., Nakamichi N., Hosotani H., Masuo Y., Sugiura T., Kato Y., PLoS One, 9 , e89434 (2014).

15) Gilley J. A., Kernie S. G., Eur. J. Neurosci., 34, 1712-1723 (2011).

16) Ogura M., Kakuda T., Takarada T., Nakamichi N., Fukumori R., Kim Y. H., Hinoi E., Yoneda Y., PLoS One, 7, e48270 (2012).
17) Islam M. O., Kanemura Y., Tajria J., Mori H., Kobayashi S., Hara M., Yamasaki M., Okano H., Miyake J., Neurosci. Res., 52, 7582 (2005).

18) Yamamoto A., Shofuda T., Islam M. O., Nakamura Y., Yamasaki M., Okano H., Kanemura Y., J. Neurosci. Res., 87, 26152623 (2009).

19) Vialou V., Balasse L., Callebert J., Launay J. M., Giros B., Gautron S., J. Neurochem., 106, 1471-1482 (2008).

20) Nakamichi N., Kato Y., Biol. Pharm. Bull., 40, 1146-1152 (2017)

21) Nakamichi N., Taguchi T., Hosotani H., Wakayama T., Shimizu T., Sugiura T., Iseki S., Kato Y., Neurochem. Int., 61, 1121-1132 (2012).

22) Ishimoto T., Nakamichi N., Nishijima H., Masuo Y., Kato Y., Neurochem. Res., 43, 116-128 (2018).

23) Tamai I., Yabuuchi H., Nezu J., Sai Y., Oku A., Shimane M., Tsuji A., FEBS Lett., 419, 107-111 (1997).

24) Gründemann D., Harlfinger S., Golz S., Geerts A., Lazar A., Berkels R., Jung N., Rubbert A., Schömig E., Proc. Natl. Acad. Sci. USA, 102, 5256-5261 (2005).

25) Gründemann D., Prev. Med., 54, S71-S74 (2012) .

26) Kato Y., Kubo Y., Iwata D., Kato S., Sudo T., Sugiura T., Kagaya T., Wakayama T., Hirayama A., Sugimoto M., Sugihara K., Kaneko S., Soga T., Asano M., Tomita M., Matsui T., Wada M., Tsuji A., Pharm. Res., 27, 832-840 (2010).

27) Bar-Peled L., Sabatini D. M., Trends Cell Biol., 24, 400-406 (2014).

28) Wolfson R. L., Chantranupong L., Saxton R. A., Shen K., Scaria S. M., Cantor J. R., Sabatini D. M., Science, 351, 43-48 (2016).

29) Nakamichi N., Nakayama K., Ishimoto T., Masuo Y., Wakayama T., Sekiguchi H., Sutoh K., Usumi K., Iseki S., Kato Y., Brain Behav., 6, e00477 (2016).

30) Park S. W., Lee J. G., Seo M. K., Lee C. H., Cho H. Y., Lee B. J., Seol W., Kim Y. H., Int. J. Neuropsychopharmacol., 17, 18311846 (2014).

31) Xu D., Sun Y., Wang C., Wang H., Wang Y., 
Zhao W., Bao G., Wang F., Cui Z., Jiang B., Neuropharmacology, 128, 181-195 (2018).

32) Li N., Lee B., Liu R. J., Banasr M., Dwyer J. M., Iwata M., Li X. Y., Aghajanian G., Duman R. S., Science, 329, 959-964 (2010) .

33) Ignácio Z. M., Réus G. Z., Arent C. O., Abelaira H. M., Pitcher M. R., Quevedo J., Br. J. Clin. Pharmacol., 82, 1280-1290 (2016).

34) Zhou W., Wang N., Yang C., Li X. M., Zhou Z. Q., Yang J. J., Eur. Psychiatry, 29, 419423 (2014).

35) Ito H., Nakajima A., Nomoto H., Furukawa S., J. Neurosci. Res., 71, 648-658 (2003).

36) Shimizu E., Hashimoto K., Okamura N., Koike K., Komatsu N., Kumakiri C., Nakazato M., Watanabe H., Shinoda N., Okada S., Iyo M., Biol. Psychiatry., 54, 70-75 (2003) .

37) Egan M. F., Kojima M., Callicott J. H., Goldberg T. E., Kolachana B. S., Bertolino A., Zaitsev E., Gold B., Goldman D., Dean M., Lu B., Weinberger D. R., Cell, 112, 257-269 (2003).

38) Colle R., Gressier F., Verstuyft C., Deflesselle E., Lépine J. P., Ferreri F., Hardy P., Guilloux J. P., Petit A. C., Fève B., Falissard B., Becquemont L., Corruble E., J. Affect. Disord., 175, 233-240 (2015) .

39) Cheah I. K., Halliwell B., Biochim. Biophys. Acta, 1822, 784-793 (2012).
40) Hurley L. L., Akinfiresoye L., Kalejaiye O., Tizabi Y., Behav. Brain Res., 268, 1-7 (2014) .

41) Seo H. J., Wang S. M., Han C., Lee S. J., Patkar A. A., Masand P. S., Pae C. U., Expert Rev. Neurother., 15, 269-280 (2015).

42) Kumaran M. S., Dabas G., Kapadia A. B., Parsad D., Dermatol. Ther., 31, e12578 (2018).

43) Qiu P., Man S., Li J., Liu J., Zhang L., Yu P., Gao W., J. Agric. Food Chem., 64, 27652771 (2016).

44) Song T. Y., Lin H. C., Chen C. L., Wu J. H., Liao J. W., Hu M. L., Free Radic. Res., 48, 1049-1060 (2014).

45) Cheah I. K., Feng L., Tang R. M. Y., Lim K. H. C., Halliwell B., Biochem. Biophys. Res. Commun., 478, 162-167 (2016).

46) Hatano T., Saiki S., Okuzumi A., Mohney R. P., Hattori N., J. Neurol. Neurosurg. Psychiatry, 87, 295-301 (2016) .

47) Pochini L., Scalise M., Galluccio M., Indiveri C., J. Biomol. Screen., 18, 851-867 (2013).

48) Tamai I., Biopharm. Drug Dispos., 34, 29-44 (2013).

49) Tikhonova M., Kulikov A. V., Chin. J. Physiol., 55, 284-293 (2012).

50) Alcalá-Barraza S. R., Lee M. S., Hanson L. R., McDonald A. A., Frey W. H. 2nd, McLoon L. K., J. Drug Target., 18, 179-190 (2010) . 